\title{
DE DIOSES Y VERSOS, DE GIGANTES Y OCÉANOS
}

ISABEL SOLER ${ }^{\mathrm{a}}$

\section{RESUMEN}

La historia de Fernando Magallanes y de la armada de las Molucas ha quedado frecuentemente eclipsada por el colosal y cruel viaje que consiguió realizar una de las naves de la expedición. Este ensayo quiere ofrecer algunas de las claves del proyecto que Magallanes propuso a Carlos I para llegar a las islas de las especias.

PALABRAS CLAVE: Fernando Magallanes, Armada de las Molucas, Patagonia.

\section{GODS AND VERSES, GIANTS AND OCEANS}

\section{ABSTRACT}

The story of Ferdinand Magellan and the Moluccan army has often been eclipsed by the colossal and cruel journey that one of the expedition's ships managed to make. This essay wants to offer some of the keys of the project that Magallanes proposed to Carlos I to reach the islands of spices.

KEY WORDS: Ferdinand Magellan, Moluccan army, Patagonia.

Theodor de Bry parece situar Hiperbórea -la tierra más allá del viento de Norte- en el recóndito e ignorado meridión americano para que Apolo, el que aparta el mal, matador de serpientes y de gigantes, protector de argonautas, guíe la nao Trinidad durante su errático paso del Estrecho. Absorto, Fernando Magallanes medita cálculos astronómicos mientras la nave sigue hacia poniente, persiguiendo el sol de la mano de este Apolo Helios que ilumina la escena. Con el rostro vuelto hacia babor, quizás el navegante se percata de los humos y hogueras de Tierra de Fuego; de espaldas a estribor, no advierte cómo el gigante patagón se mete, dos palmos o más, una flecha por la garganta. Tal vez es Tetis esa bella nereida, la sirena que señala el rumbo con la mano derecha, mientras con la izquierda se sujeta la larga cola, creando un círculo que vaticina el redondo dibujo del mundo que solo una de las naves de las Molucas conseguirá realizar. En la esquina superior izquierda,

a Facultad de Filología y Comunicación de la Universidad de Barcelona. \ isabelsoler@ub.edu 
el enorme pájaro Garuda, devorador y solar -el ave rukh persa, el grifo griego, el renaciente fénix, el Roc que Marco Polo sitúa en Zanzíbar-, sujeta con sus garras al elefante mientras vuela hacia el árbol caiu pauganghi. Frente a ellos, Céfiro, el duro viento del oeste, sopla con fuerza mientras Zeus contempla la inédita escena ${ }^{1}$. Ningún europeo había llegado nunca hasta aquellas heladas y ventosas latitudes, ninguna nave peninsular había cruzado antes aquel estrecho del fin del mundo.

No es la primera vez que los dioses ayudan a un navegante portugués que se aventura por aguas desconocidas. El brillante Apolo conduce a Magallanes entre el frío y el viento del meridión americano, como, tres décadas antes, 1497-1499, Venus había guiado a Vasco de Gama (y a todo un pueblo navegante y descubridor, heroicamente lusíada) en la circunnavegación del tormentoso cabo de Buena Esperanza y en la singladura de un Índico ya muy transitado desde antiguo, pero nunca por naves occidentales. Como el propio Magallanes en 1505, el poeta-soldado Luís Vaz de Camões supo en 1553 lo activos que necesariamente debían estar los hombres en ese paso del cabo de las tormentas que, años después y desde los versos, habrá de custodiar el pétreo titán Adamastor; también supo de la atención de la marinería a vientos y corrientes y a atolones y bajíos -las trampas y engaños del asiático dios Bacodurante la navegación del Índico. Sin embargo, tan estático parece Magallanes en la imagen elegida por Theodor de Bry como inexpresivo lo es Vasco de Gama en las octavas reales lusíadas que narran la epopeya argonáutica a la India. Los dioses se encargan del buen fin de la derrota.

1 De Bry, 1594. Inventio Maris Magallanici, Americae Pars Quarta. Lám. 15. El editor y también grabador belga Theodor de Bry, gran difusor de las novedades del mundo mediante sus ediciones por entregas entre 1590 y 1634 de imágenes de la conquista y colonización de América por los españoles, e instigador, a su vez, de la llamada leyenda negra, se sirvió de las cuatro imágenes alegóricas Americae Retectio (1589) elaboradas por el pintor belga Jan Van der Straert y grabadas por Adriaen Collaert, para su edición Americae de la serie Grandes Viajes.

2 De todos los testimonios conservados sobre el viaje de circunnavegación del globo, el más extenso y detallado (aunque omite algunos sucesos importantes) es el del italiano Antonio Pigafetta, del que se conservan cuatro copias manuscritas, ninguna de su mano, en la Biblioteca Ambrosiana de Milán (en italiano, castellano y dialecto
No es probable que Theodor de Bry leyera Os Lusíadas, publicados en marzo de 1572, cincuenta años después de la violenta muerte de Fernando Magallanes en la pequeña isla filipina de Mactán, y asimismo es poco verosímil que leyeran la epopeya tanto Jan Van der Straert como Adriaen Collaert, autores del precioso grabado alegórico, pero la presencia en la imagen del Garuda que vuela con el elefante en sus garras y el Patagón en acto de purgarse el estómago parece demostrar que habían leído a Antonio Pigafetta. No sería el documento original del viaje a las Molucas que el aventurero lombardo fue escribiendo día a día desde agosto de 1519 y que entregó al emperador Carlos a principios de septiembre de 1522; quizás, aunque es poco probable, ilustradores y editor leyeran el resumen en francés que se publicó en París entre 1526 y 1536 a instancias de la reina regente de Francia, Luisa de Saboya, quien había recibido del propio Pigafetta un relato en italiano. De esa edición se elaboraría en 1536 la primera italiana, Il viaggio fatto dagli Spagnoli atorno al mondo, formando parte de una antología en la que también se incluyó la famosa carta del secretario Maximiliano Transilvano. Seguramente fue la segunda edición de ese texto la que leyó de Bry, porque Gian Battista Ramusio la incluyó en 1550 en el primer volumen de sus muy divulgados y reeditados Navigazioni e viaggi; aunque, sin duda, también pudo llegar a tener acceso a uno de los diversos manuscritos que circulaban por Europa y se leían con interés, admiración y sorpresa ${ }^{2}$. Tras su terrible y soberbia aventura de casi tres años y setenta mil kilómetros, ya habiéndose presentado ante el emperador, salió Pigafetta de España lo antes que pude, dice con

véneto), dos en la Biblioteca Nacional de París (en francés) y uno pertenece a la colección particular de FitzRoy de Fenwich (también en francés), actualmente depositado en la biblioteca de la Universidad de Yale. El de la Biblioteca Ambrosiana, "Notizie del Mondo nuovo con le figure de paesi scoperti descritte da Ant. ${ }^{\circ}$ Pigafeta vicentino cavaglieri da Rodi”, ms. L103 Sub, es el más completo. Se sigue en estas páginas la edición en castellano elaborada por Riquer, 1999. El primer viaje alrededor del mundo. Ediciones B, a partir de la de Mario Pozzi: Pigafetta, 1994. Il primo viaggio intorno al mondo con il Trattato della sfera. Neri Pozza Editore, Vicenza, 2 vols. Y se sigue a su vez, la imprescindible edición de Castro, Hamon y Thomaz (Eds.), 2007. Le voyage de Magellan: La relation d'Antonio Pigafetta et autres témoignages. Éditions Chandeigne, Paris, 2 vols. 
discreción, aunque se advierte en la frase evidente incomodidad, para presentarse primero en la corte de D. João III de Portugal y después en la de Francia. El siguiente paso fue Mantua, donde en la corte de Isabel d'Este Gonzaga empezó a escribir de nuevo su relato. Volvió a explicar su aventura en Venecia y, mientras se dirigía a la Roma del papa Clemente VII, se detuvo en Monterosi, cerca de Viterbo, donde se encontraba el gran maestre de los Caballeros Hospitalarios, Philippe Villiers de l'Isle-Adam, que acababa de perder Rodas frente a Solimán el Magnífico. Allí fue a reunirse con él Antonio Pigafetta y se ha dicho que fue entonces cuando el gran maestre le nombró caballero de la Orden. Sin embargo, de la dedicatoria e introducción a su Notizie del Mondo Nuovo se desprende que ya lo debía ser, o al menos, Pigafetta da a entender que ya se conocían. Como Hospitalario, quizás el vicentino había luchado contra el Turco en el Mediterráneo antes de zarpar hacia las Molucas, y puede que eso explique la buena relación -la manifiesta admiración- con su capitán mayor Magallanes, que era caballero de la Orden de Santiago (desde hacía poco, eso también es cierto: el rey Carlos le había otorgado el título antes de zarpar de Sevilla en 1519). En cualquier caso, el gran maestre Villiers de l'Isle-Adam incitó a Pigafetta a volver a escribir su aventura y éste le dedicó la historia del viaje de la vuelta al mundo que había protagonizado.

A su vez, Camões llevaba tres años en Lisboa, tras haber pasado más de una década y media en Oriente, cuando en 1572 apareció publicada su enorme epopeya ${ }^{3}$. El suyo no fue el mismo Oriente al que había llegado Magallanes en 1505 y del que regresó en 1513, pero sin duda el poeta aventurero conoció muchos de los lugares indostánicos y extremo-orientales en los que había estado el apátrida navegante antes de regresar a Portugal y antes de cruzar la frontera rumbo a Sevilla. En Oriente empezó Camões a escribir muchos de los casi nueve mil versos de la gesta de Vasco de Gama, y es ese un poema que tiene mucho de oracular y premonitorio, además, como es bien sabido, de muchos dioses. Entre el bullicio de la despedida, el Canto IV contiene los oscuros vaticinios del sabio y experimentado

3 Se sigue aquí la edición a cargo de da Costa Pimpão, Luís Vaz de Camões, 1989. Os Lusíadas. Ministério da
Velho do Restelo, justo antes de que las naves gámicas larguen del puerto de Lisboa, y como un alter ego del poeta, cuenta el viejo navegante lo que será la historia marítima portuguesa desde un pesimismo denunciativo de la codicia de riquezas y de fama que mueve el viaje oceánico desde sus orígenes. En el Canto $V$, ya en los confines del mundo, cuando las naves superen el cabo de Buena Esperanza, el imponente titán Adamastor, triste y profético, repetirá con mayor tragicidad una historia portuguesa del mar llena de tormentas y naufragios, porque, dice solemne y severo, em vossas naus verei, cada ano, / se é verdade o que meu juízo alcança, / naufrágios, perdições de toda sorte, / que o menor mal de todos seja a morte! (V, 44, 5-8).

Y así va siguiendo el relato de esta historia trágico-marítima pasada, presente y futura hasta que en el Canto $\mathrm{X}$, mientras los nautas reciben su deleitoso premio en la Ilha dos Amores por la gran gesta alcanzada, la bella ninfa Tetis se aparta con Vasco de Gama para mostrarle la Grande Máquina do Mundo y para revelarle al capitán mayor mucho de lo que será, a partir de este primer viaje iniciático de 1497-1499, la Carrera de Indias no tanto de Portugal, como de los portugueses. Por eso, por los portugueses, en ese largo y revelador parlamento del Canto $\mathrm{X}$ que recorre todo Oriente y sus contenidos y realidades, aparece, como no podía ser de otro modo, el futuro Fernando Magallanes: Mas é também razão que, no Ponente, / dum Lusitano um feito inda vejais, / que de seu Rei mostando-se agravado, / caminho há-de fazer nunca cuidado (X, 138, 5-8). Un lusitano agraviado por su rey hará un camino hacia poniente nunca antes pensado; y es cierto lo que dice la hermosa ninfa marina: tras su regreso de Oriente, Magallanes se sintió maltratado por el rey D. Manuel I y Vasco de Gama supo de ese agravio. Y también supo de las consecuencias de ese agravio: la traición de Magallanes a su rey y el impensado camino hacia poniente que el apátrida emprendía al servicio de Carlos I para demostrar a qué lado del contrameridiano de Tordesillas se encontraban las deseadas islas del Moluco. Y Vasco de Gama se enfadó

Educação, Instituto de Cultura Portuguesa, Lisboa. 
mucho con Magallanes, aunque se enfadó años después de la expedición a las Molucas, cuando ya era virrey de la India y cuando se hicieron evidentes las repercusiones -más políticas que económicas- del viaje magallánico. Fue entonces cuando Gama se permitió opinar, según cuenta el cronista Gaspar Correia, sobre lo que hubiera tenido que haber hecho el rey Manuel con el apátrida Magallanes: se El-Rei mandara cortar a cabeça a Fernão de Magalhães, quando se arrufou de lhe nom acrecentar a moradia, nom lhe fizera o que lhe fez ${ }^{4}$.

Ciertamente, Magallanes se sentía mal pagado por los servicios prestados durante sus ocho años en Oriente, y así lo manifestó en diversas ocasiones; pero el siempre malhumorado Vasco de Gama parece haber olvidado que también él estuvo a punto de traicionar a su rey -aunque eso no se lo vaticine la nereida Tetis en la Ilha dos Amores-, porque en 1518, un año después de que Magallanes se instalara en Sevilla, el rey Manuel tuvo que impedir que el incómodo Vasco de Gama cruzara la frontera y supuestamente se ofreciese en servicio a Carlos I si el monarca portugués no le concedía el título de conde, como entendía que le había prometido ${ }^{5}$. Parece que Vasco de Gama, el Almirante del Mar Océano, le planteaba una especie de chantaje a Manuel, aunque difícilmente podía éste estar inspirado por Magallanes, del que ni siquiera debía de tener noticia en aquellas fechas, por mucho que la sabia Tetis se lo hubiera explicado ante la Grande Máquina do Mundo en la Ilha dos Amores ya de regreso de su poética odisea a la India.

Camões sabía de qué hablaba cuando rimaba los versos sobre Magallanes, y también cuando hacía que Tetis le describiera a Vasco de Gama los deseados productos que producen las islas del Moluco; y lo sabía porque había estado alli. Le dice la ninfa a Vasco de Gama que mire pelos mares do Oriente / as infinitas ilhas espalhadas: / Vê Tidore e Ternate, co fervente

4 Si el Rey hubiera mandado cortarle la cabeza a Fernão de Magalhães cuando este se crispó por no haberle aumentado la moradia, no le hubiera hecho lo que le hizo, Correia, 1975. Lendas da Índia. Lello \& Irmão, Oporto, Vol. III, p. 662.

5 Un desarrollo de las complejas relaciones entre el rey Manuel y Vasco de Gama en Un acometimiento grande
/ cume, que lança as flamas ondeadas [en referencia al volcán Gamalama]/ As árvores verás do cravo ardente, / co sangue português ainda compradas [...]// Olha de Banda as ilhas, que se esmaltam / da vária cor que pinta o roxo fruto; / as aves variadas que ali saltam / da verde noz tomando seu tributo (X, 132-133). Ciertamente, el Pacífico posee muchas más islas, coralinas y volcánicas, que el resto de los otros océanos juntos, y la gran mayoría estaban pobladas y ofrecían desde antiguo sus riquezas naturales, como ya supo Vasco de Gama en su primer viaje a la India. No muestra sorpresa cuando Tetis le enseña el clavo de las Molucas de Norte, la nuez moscada y el macis del volcánico archipiélago de Banda, también le habla del sándalo de Timor y del rico reino de Sunda en la isla de Java, del alcanfor de Borneo, del benjuí de Sumatra (X, 132135). Todas esas riquezas también las aprendió Magallanes in situ justo en el momento en el que el gobernador Afonso de Albuquerque, artífice y fundador del Estado Português da Índia, mandaba que fueran explorados todos aquellos racimos de islas. En agosto de 1511 estaba Magallanes junto a Albuquerque en la conquista de Malaca, y allí estaba también, como era costumbre desde que en 1505 zarparon de Lisboa, su amigo Francisco Serrão. En 1511, el gobernador Albuquerque ya poseía la deseada Malaca, el paso hacia Extremo Oriente y el Pacífico, la posición idónea para dominar el golfo de Bengala, Insulindia, Indochina y el sur de China ${ }^{6}$; y mientras se construía la consabida fortaleza, también se enviaban naves hacia el este con la misión de explorar y recabar información político-mercantil. En Malaca estuvo Magallanes un año y medio, hasta que el 11 de enero de 1513 zarpó hacia Lisboa. Y puede que durante ese tiempo se enrolase en una de esas armadas de exploración. Aparece aquí una de las grandes incógnitas que suscita la experiencia biográfica de Magallanes en Oriente, que es saber si realmente embarcó en una de las tres

y grave, en Soler, 2011. Derrota de Vasco de Gama. Acantilado, Barcelona, pp. 80-86.

6 Sobre los portugueses en Malaca, véase Thomaz, 2000. Early Portuguese Malacca. Comissão Territorial de Macau para as Comemorações dos Descobrimentos Portugueses, Instituto Politécnico de Macau, Macao. 
naves que en 1511 Afonso de Albuquerque mandó a cargo de António de Abreu a las islas de Ambon, Seram y Banda ${ }^{7}$, porque entre los pocos nombres que han quedado recogidos de los que formaron parte de la tripulación no aparece el de Magallanes, pero sí el de su inseparable compañero de aventuras Francisco Serrão, que capitaneaba una de las naves. El cronista Fernão Lopes de Castanheda da a entender abiertamente que Magallanes estuvo allí: o mesmo Fernão de Magalhães fora testemunha del viaje de António de Abreu, tendo a certeza onde aquelas ilhas jazião ${ }^{8}$, refiriéndose a las Molucas, pero lo cierto es que esa expedición no alcanzó propiamente el archipiélago, aunque sí cargó clavo y nuez moscada en la isla de Banda antes de regresar a Malaca. En cualquier caso, respecto a esa empresa, lo más interesante para la biografía de Fernando Magallanes es que la embarcación de su amigo Francisco Serrão naufragó en la deshabitada isla de las Tartarugas (Nusa Penju, en el archipiélago Kepuluauan Lucipara) y no regresó con António de Abreu. Parece que los náufragos pasaron alli dos meses hasta que se apoderaron de un junco, consiguieron llegar a Ambon, y de allí, a Ternate; y dice el cronista António Galvão que alli se quedaron los portugueses siete u ocho años ${ }^{9}$. Y más tiempo también se debieron de quedar, porque, aunque se le esperaba en Malaca y hasta se le fue a buscar, Francisco Serrão no se movió de las Molucas hasta el día de su muerte, en 1521, y desde allí fue escribiendo cartas a Magallanes y esperando su llegada mientras se ganaba la confianza del rey de Ternate y adquiría total libertad de acción ${ }^{10}$.

Que el nombre de Magallanes no conste entre los pocos que fueron anotados de entre los que formaban parte de la expedición de António de

7 Rêgo, 1975, As Molucas em princípios do século XVI, Junta de Investigações Científicas do Ultramar. A Viagem de Fernão de Magalhães e a Questião das Molucas. Actas do $2^{\circ}$ Coloquio Luso-Espanhol de História Ultramarina. Junta de Investigações Científicas do Ultramar, Lisboa, pp. 77-89; Frade, 2002. As primeiras viagens às ilhas de Maluco, Fernão de Magalhães e a Sua Viagem no Pacífico: Antecedentes e Consequentes. Academia da Marinha, Actas do VII Simpósio de História Marítima, 24 a 26 de Outubro de 2001, Academia da Marinha, Lisboa, pp. 5169.

8 Castanheda, 1979. História do descobrimento \&
Abreu no quiere decir que no hubiera embarcado. Puede que hubiera ido, pero sin desempeñar ningún cargo importante y sin protagonizar ninguna acción destacable que valiera la pena registrar. También cabe la hipótesis de que sí se hubiera dispuesto de esa información, pero que, vistas las posteriores consecuencias para Portugal y para España de la experiencia oriental del portugués, no hubiera sido recogida o directamente se eliminase, para evitar que quedase constancia oficial de la presencia de Magallanes en las Molucas antes de 1519. Siguiendo en el ámbito de las suposiciones, dado el carácter ambicioso de Magallanes, cuesta pensar que se hubiera quedado en Malaca mientras zarpaba una gran expedición en busca de una de las especias más raras, caras y difíciles de adquirir de la época, y en la que, además, iba su amigo Francisco Serrão. En cualquier caso, si Magallanes fue realmente a Banda en esa armada, no se quedó con su amigo Serrão -ya no se volverían a ver nunca más-, sino que regresó a Malaca con António de Abreu $^{11}$. Y también con Abreu abandonó Malaca en enero de 1513 hasta Cochin, donde juntos embarcaron de regreso a Portugal; Magallanes se llevaba de Malaca a su criado malayo Henrique.

Cuando a mediados de 1513 regresó a Lisboa después de haber pasado ocho años en Oriente, contrariamente a lo que se suele pensar, no ofreció su proyecto al rey Manuel. Es fácil caer en la tentación de imaginar a Magallanes proponiendo a su rey la posibilidad de llegar al preciado clavo de las islas Molucas siguiendo una ruta hacia el oeste, como veinte años antes había hecho el genovés Cristóbal Colón ante el rey D. João II para llegar a la pimienta indostánica. No fue así. Lo único que une a Cristóbal Colón y a Magallanes, aparte del rumbo de sus naves, es que ambos cruzaron la frontera portuguesa para ofrecer sus proyectos

conquista da Índia pelos Portugueses. Lello \& Irmão, Oporto, Vol. II, p. 442.

9 Galvão, 1987. Tratado dos Descobrimentos. Ed. del vizconde de Lagoa, Livraria Civilização, Oporto, p. 107.

10 Sobre Francisco Serrão véase Lobato, 2011. As especiarias indonésias na economia mundo e a génese do primeiro conflito entre potências europeias à escala mundial. En As Ilhas e a Europa, a Europa das Ilhas, Centro de Estudos de História do Atlântico, Funchal.

11 Garcia, 2007. A Viagem de Fernão de Magalhães e os portugueses. Presença, Lisboa, pp. 23-27; Castro, Hamon y Thomaz (Eds.), 2007, op. cit., pp. 317-319. 
a reyes españoles. Las de Colón y Magallanes fueron iniciativas propias, ambas gestadas en Portugal y gracias a los avances de los viajes portugueses, y eran ideas muy osadas que entraban en conflicto con los intereses político-económicos y diplomáticos de la corona portuguesa. Y aun a pesar de poder herir sensibilidades, cabe aceptar que, en justicia, los viajes de Colón y Magallanes no cumplieron sus propósitos: el genovés no llegó a Catay ni se entrevistó con el Gran Khan y el portugués no llegó a las Molucas -al menos no entre 1519 y 1521- ni consiguió demostrar a qué lado del contrameridiano de Tordesillas se encontraba el archipiélago. Aunque evidentemente, el valor de esas experiencias no está en su fracaso, sino en la trascendencia de la gesta realizada y de la realidad encontrada.

A Manuel ya le llegaba a Lisboa el clavo y la nuez moscada, solo tenía que esperar con paciencia los largos meses que sus naves necesitaban para hacer la ruta del Cabo. No, durante los cuatro años que Magallanes estuvo en Lisboa desde que llegó de la India hasta que cruzó hacia Sevilla, el plan para volver a las Molucas no pasaba por atravesar el Atlántico. Cabe pensar, aunque se pueden manejar otras hipótesis, que Magallanes cambió de plan cuando se enfadó con el rey, y el disgusto le vino por diversos agravios que no hay espacio para contar aquí, pero que básicamente tienen que ver con dinero y prestigio ${ }^{12}$. En realidad, el caso de Magallanes era muy común, el navegante era uno más de los muchos agraviados por el proyecto expansivo manuelino. En realidad, casi todos los héroes del viaje oceánico (tanto portugués como castellano), por muy indiscutiblemente heroicos que fueran sus viajes, se sintieron maltratados o poco reconocidos por sus reyes. La gloria y la fama -o el descrédito y el deshonor- les llegaron después, cuando los cronistas empezaron a construir la historia marítima peninsular, y los sucesivos historiadores del viaje la fueron rescribiendo. En cualquier caso, en 1513 Magallanes no era un héroe, era alguien que había embarcado hacia la India y había conseguido volver sin perder la vida. Era alguien casi tan desconocido como el joven Magallanes que en 1505 había embarcado hacia

12 Véase Soler, 2015. El sueño del rey: viajes y mesianismo en el Renacimiento peninsular. Acantilado, Barcelona,
Oriente. En 1513, Magallanes llevaba muchas millas náuticas encima, muchas batallas, muchas imágenes de lo desconocido, mucha geografía impensada. De hecho, había estado en lugares que no estaban en el dibujo del mundo, y había regresado con una idea. O una vez en Lisboa había empezado a amasar una idea. Y la consumación de esa idea pasaba por la traición.

Eso es lo que le revelará la nereida Tetis a Vasco de Gama en su progresivo avance por el mapa del mundo desde Oriente hacia Occidente. Empieza en la estancia 139 del Canto X al explicarle al capitán mayor lo que es América: una gran tierra que, continua, va desde Calisto ao seu contrario Pólo, es decir, del Polo Norte al Polo Sur, y que la lucente mina / do metal que a cor tem do louro Apolo hará soberbia. América es, pues, enorme y rica en oro, dorada como Apolo; pero también Castilla, dice Tetis, será dina / de lançar-lhe o colar ao rudo colo. Castilla la someterá. Sí, ya era así cuando en 1572 Camões consiguió publicar su larga epopeya, y hasta Portugal estaba a punto de ser sometida por Castilla -por España, por el Imperio-, pero eso no lo llegó a ver el viejo soldadopoeta, que murió en 1580 , dos años después de la desastrosa batalla de Alcazarquivir y un año antes de que Felipe II fuera proclamado en las Cortes de Tomar. Pero aún falta mucho para eso, y no lo cuenta Tetis, obviamente. Por el contrario, la ninfa se da prisa en la estancia 140 en puntualizar las geografías y dice que allí donde más se alarga América tereis / parte também, la tierra del paubrasil a la que Santa Cruz o nome lhe poreis, en clara alusión a la expedición del año 1500 (apenas un año después del regreso de Vasco de Gama de la India) bajo el mando de Pedro Álvares Cabral. Y especifica Tetis para que quede claro: Descobri-la-á a primeira vossa frota, para que no haya duda de que Brasil pertenece a Portugal porque llegó primero. Es entonces cuando Tetis eleva los duros y dolorosos versos de la traición: Ao longo desta costa, que tereis, / irá buscando a parte mais remota / o Magalhães, no feito, com verdade, / português, porém não na lealdade (X, 140). La parte más remota de esa costa la busca un portugués, que ha dejado de serlo por deslealtad. 
Termina Tetis sus vaticinios sobre las gestas oceánicas de los portugueses con el viaje del ingrato Magallanes, y dice que, cerca ya del Polo antártico duma estatura quase giganteia / homens verá, da terra ali vizinha; / e mais avante o Estreito que se arreia / co nome dele agora, o qual caminha / para outro mar e terra que fica onde / com suas frias asas o Austro a esconde (X, 141). El frío sur esconde con sus alas una tierra que se abre a otro mar y en la que habitan gigantes. Y así va a ser y así se la va a llamar, región de Magallanes, estrecho de Magallanes. Sin embargo, contrariamente a lo que dicen los versos lusíadas, Magallanes no los bautizó con su propio nombre, sino que los llamó, dice Pigafetta, tierra Patagonia y estrecho patagónico; $y$ es alli donde se iban a concentrar los grandes descubrimientos de aquella expedición a las islas del clavo y la nuez moscada.

Quizás en este punto cabe recordar que para el navegante portugués el mundo conocido estaba al final del viaje, y era aquel un mundo poblado, transitado y conectado, y en el que ya había estado. Para Magallanes, el mundo desconocido estaba al otro lado del Atlántico, en la larga costa americana que debía recorrer hasta encontrar un paso que le permitiera superar el gran inconveniente geográfico que parecía ser América. Porque desde el pensamiento especiero, eso es exactamente lo que era América, un problema geográfico, y la obsesión por hallar el paso que permitiera solventar el problema había empezado desde muy temprano, entre 1500 y 1502, con las expediciones de Gaspar Corte Real hacia el norte y las de João da Nova y Gonçalo Coelho, en la que participó Vespucio, hacia el sur, y se reavivó en 1511 con la silenciosa expedición de João de Lisboa, a quien el cronista Gaspar Correia atribuye el descubrimiento del cabo de Santa Maria y hasta el del río de la Plata. Tras

13 Para un mayor pormenor, véase, Guedes, 1975. As primeiras expedições de reconhecimento da costa brasileira. História Naval Brasileira, Rio de Janeiro, Vol. I, Tomo I, parte 2 .

14 Alguns, 1892. Documentos do Arquivo Nacional da Torre do Tombo acerca das Navegações e Conquistas Portuguesas. Imprensa Nacional, Lisboa, pp. 431435; sobre los cartógrafos Reinel véase también Amaral, 1995. "Pedro Reinel me fez". À Volta de um Mapa dos Descobrimentos. Quetzal Editores, Lisboa; y Moreira, 2015. Pedro e Jorge Reinel (at. 1504-60): Dois cartógrafos negros na corte de D. Manuel de Portugal (1495- la llegada a Castilla de las noticias tanto de João de Lisboa como de Vasco Núñez de Balboa, hacia el sur y con el mayor sigilo mandó el rey Fernando en octubre de 1515 a otro célebre portugués apátrida, Juan Díaz de Solís, quien, éste sí, llegó el 20 de enero de 1516 al gran estuario del río de la Plata, donde murió a manos de los indios charrúas ${ }^{13}$. La de Magallanes era la segunda expedición castellana hacia aquellas latitudes. Él nunca había cruzado el Atlántico, pero tampoco partía a ciegas, llevaba buenos mapas, los que le habían preparado los cartógrafos portugueses Pedro y Jorge Reinel, padre e hijo, y Diogo Ribeiro ${ }^{14}$. Fue, no obstante, un viaje enormemente dificultoso, ya durante los años de preparación en Sevilla, desde 1517 a 1519 , y, como es de sobras conocido, durante las singladuras oceánicas hasta llegar a las Filipinas y de allí, ya sin Fernando Magallanes, hasta Sevilla en septiembre de 1522 .

En ninguno de los documentos que refieren esos viajes al sur previos a la armada de las Molucas aparecen los términos Patagonia o patagones. El primero en recogerlos fue Antonio Pigafetta, y cabe puntualizar, dada la histórica tradición que así lo interpreta, que en ningún momento alude el italiano a las grandes dimensiones de los pies de los indígenas allí hallados como motivo para llamarlos de este modo, aunque sí dice (dos folios antes de bautizarlos como patagones) que llevan los pies envueltos en pieles. La alusión a la gran huella que dejan los naturales de aquellas latitudes pertenece al relato de la segunda expedición a las Molucas, la de García Jofre de Loaísa, que zarpó en 1525 desde A Coruña y en la que iban Andrés de Urdaneta y, de nuevo, Juan Sebastián Elcano, que murió, y de la que, después de infinidad de avatares, consiguieron regresar veinticuatro supervivientes en 1536. Gonzalo Fernández de Oviedo recoge el

1521). Terra Brasilis [on-line] 4, disponible en https:// journals.openedition.org/terrabrasilis/1209 [acceso el 25-04-2019]; sobre la cartografía del viaje magallánico véase Sandman, 2007. Spanish Nautical Cartography in the Renaissance. En Woodward (Ed.), History of Cartography-Volume Three: Cartography in the European Renaissance, Part. 1, The University of Chicago Press, Chicago, pp. 1111-1116; y Sánchez, 2009. De la 'cartografía oficial' a la 'cartografía jurídica': la querella de las Molucas reconsiderada, 1479-1529. Nuevo Mundo/ Mundos Nuevos, http://nuevomundo.revues.org/56899 [acceso el 25-04-2019]. 
relato en el Libro XX de la segunda parte de la General historia de las Indias, publicado en 1557, y allí explica que una costa y la otra del estrecho de Magallanes es habitada de gigantes a los cuales nuestros españoles llamaron patagones por sus grandes pies ${ }^{15}$. En cualquier caso, no le llaman especialmente la atención a Pigafetta las dimensiones de los pies de los patagones, porque, de ser así, lo hubiera registrado. Y tuvo tiempo para ello, no solo porque en la bahía de San Julián pasaron las naves cinco meses, desde el 31 de marzo al 24 de agosto de 1520, y tuvieron tiempo sobrado de relacionarse con los tehuelches, sino porque uno de los cuatro glosarios que incluye Pigafetta en su relato está dedicado a la lengua de los gigantes patagones y recoge ochenta y ocho palabras, de las cuales, las primeras cuarenta y dos responden a partes del cuerpo y ahí cabe destacar que los pies ocupan el lugar treinta y siete, después de términos tan precisos como los que responden a los agujeros de la nariz, las palmas de las manos, las axilas, los testículos, la vagina, el culo o las nalgas, siguiendo un meticuloso orden progresivo que va de las partes más altas de la anatomía humana a las más bajas. Los pies de los patagones le interesan tanto a Pigafetta como cualquier otra zona de sus cuerpos. Eso sí, aquellos cuerpos los ve de aspecto gigantesco aquel 19 de mayo de 1520 en el que, en la bahía de San Julián, un hombre, un tehuelche, estaba sobre la arena casi desnudo y cantaba y danzaba al mismo tiempo, echándose polvo sobre la cabeza. Cuando lo tuvieron delante, era tan grande, aunque bien proporcionado, que nuestras cabezas llegaban apenas a su cintura; tenía la cara completamente pintada de rojo y alrededor de los ojos de amarillo y en las mejillas llevaba pintados dos corazones. El pelo lo llevaba embadurnado de blanco e iba vestido con pieles de guanaco, animal que Pigafetta describe con cabeza y orejas de mula, cuerpo de camello, patas de ciervo y cola de caballo, al más puro estilo de la literatura de viajes. Iba armado con arco y flechas, muy largas, con la punta de pedernal [...] como las

15 Fernández de Oviedo, 1557. Libro XX de la segunda parte de la General historia de las Indias. Valladolid, Francisco Fernández de Córdoba, cap. 13, f. XXXIII r, disponible en http://bibliotecadigital.aecid.es/bibliodig/ es/consulta/registro.cmd?id=746 [acceso el 07/05/2019]. Véase el pormenorizado análisis de Doura, 2011. Acerca flechas turcas, puntualiza el caballero de Rodas. El patagón se miró en un espejo y se pegó tal susto que del salto derribó a cuatro hombres. Se fue a su casa con unos cascabeles, un espejo, un peine y algunos paternoster, es decir, diversas chucherías y unos rosarios. Hubo uno, más confiado, que hasta se pasó siete días en las naves, bailando y repitiendo palabras que le enseñaban -Jesús, Padrenuestro, Ave María-, tenía una voz potente y pronunciaba bien, le llamaron Juan ${ }^{16}$.

$\mathrm{Si}$ los pies de los habitantes del remoto meridión americano captaron la atención de navegantes e historiadores de navegantes, una vez quedó ya claro que nada tenía que ver el nombre de los indígenas con las dimensiones de sus extremidades inferiores, la palabra patagón ha llenado largas páginas de filólogos e historiadores de la lengua que han ofrecido las más variadas teorías. Algunas de ellas han resultado ser bastante divertidas, como la de que había muchos patos por aquella tierra o que aquella gente sufría la enfermedad llamada patago, la cual les impedía mover la lengua. No, los patagones hablaban bien, articulaban con mucha claridad y con voz poderosa, aunque a su manera, como dice Pigafetta al final de su glosario: Todas estas palabras se pronuncian con la garganta, porque así las pronuncian ellos, en alusión al carácter glotal de las consonantes oclusivas en lengua tehuelche $e^{17}$. Al escarbar en el tehuelche, se ha descubierto que 'pata' significa siete y 'gon', codo, por lo que patagón significaría 'siete codos', en referencia a la altura de los gigantes encontrados. También la lengua pampa ha servido para encontrar una explicación, la de tierra rota, ya que 'thagón' quiere decir quebrar, y además, toda aquella es una zona de seísmos y terremotos. No parece que entre las muchas cosas que le pasó a la armada de las Molucas a partir de los $49^{\circ} \mathrm{S}$ en adelante estuviera la de vivir un seísmo. De ser así, Pigafetta habría preguntado el nombre y lo habría registrado. La Tierra de las muchas colinas sería otra posibilidad, al ser 'pata' cerro o colina, con su plural 'cuna', pero

del topónimo Patagonia, una nueva hipótesis de su génesis. Nueva Revista de Filología Hispánica, LIX, núm. 1, pp. 37-78.

16 Pigafetta, 1999, op. cit., pp. 90-93 y 107-109.

17 Ibidem, p. 93 y 109 
eso sería en lengua quichua, que se hablaba en las zonas andinas del norte, bajo dominio Inca. La otra opción entre las lenguas autóctonas sería en la que se comunicaban los yámanas de Tierra de Fuego, por la que 'patag-önia' querría decir lugar ancho o amplio. Pero como es bien sabido, de los yámanas apenas vieron el humo de sus hogueras los navegantes de las Molucas ${ }^{18}$.

Queda, por tanto, la opción que parece más lógica, que es la de las diferentes lenguas románicas que se hablaban en las naves, el castellano y el portugués, que eran las dos mayoritarias, y la del autor del relato, que era el italiano. Cabe advertir que, aunque la armada partía con estandarte español, la tripulación estaba constituida por una variedad importante de nacionalidades, de entre las cuales dominaba la española, conformada por ciento treinta y nueve embarcados, seguida de la portuguesa, formada por treinta y uno, entre marinería técnicos y oficiales, aunque es lícito sospechar que algunos de esos tantos españoles fueran en realidad portugueses que al enrolarse habían españolizado el nombre, dada la explícita prohibición de última hora de portugueses a bordo. Pero también iban en la armada veintiséis italianos, nueve griegos, cinco flamencos, cuatro alemanes, dos irlandeses, un inglés, dos esclavos negros, un indio de Goa, un esclavo de Malaca y dos mestizos, por lo que la variedad lingüística en las cinco naves es una circunstancia a tener en cuenta y a la que pocas veces la historiografía ha prestado atención ${ }^{19}$.

En cualquier caso, recién llegados a finales de marzo de 1520 a la bahía de San Julián, y antes del terrible motín del mes de julio que Magallanes atajó con brutalidad y sobre el que Pigafetta pasa de puntillas, el italiano dedica dos meses a describir aspecto, reacciones y costumbres de los indios que alli encontraron. $\mathrm{Y}$ al final de esas largas páginas, escribe el capitán general llamó a estos pueblos patagones, obviamente, el italiano escribe patagoni. Se ha aventurado que el término derive de pata de cão, en portugués -pata de can, sería en castellano, quizás otra vez pensando en la piel peluda del calzado-, sincopado en patacão, con su plural patacões, que evolucionaría en patagones.

18 Véase una larga justificación de todas estas hipótesis en Doura, 2011, op. cit., pp. 48-53.

19 Castro, Hamon y Thomaz (Eds.), 2007, op. cit., Vol. I, p.
Podría ser. La que realmente chirría un poco es la metáfora de la moneda de cobre de poco valor llamada patacão acuñada en el siglo XVI, por la que los patagones serían gentes de poco valor ${ }^{20}$.

Modestamente, se aventura aquí otra hipótesis. En este sentido cabe advertir que patacão, pudiendo muy bien ser una moneda, sobre todo era en portugués, y también en castellano, un adjetivo ya en uso en el siglo XVI que definía a una persona poco inteligente, poco razonable o directamente necio, también a alguien zafio o rústico. Quizás la palabra le vino a la mente a Magallanes al observar, en aquel invierno en San Julián en la que la temperatura difícilmente superaba los cero grados, a un hombre casi desnudo, cantando y bailando y echándose tierra por la cabeza, con la cara pintada de rojo y amarillo, o al advertir en los hombres que vieron posteriormente, y con los que socializaron, que rápidamente y a la mínima ocasión se ponían a bailar y a dar saltos, o que eran tan fáciles de apresar al llenarles las manos de regalos y ofrecerles al mismo tiempo unos grilletes, que, obviamente, no podían coger, por lo que el capitán mayor les dijo por señas que se los pondría en los pies y asi se los podrían llevar con facilidad. Esta fue la manera muy astuta con la que Magallanes capturó a los dos más jóvenes y de mejor aspecto para llevarlos a España. Y quizás ya fue definitivo advertir que cuando a esta gente les duele el estómago, en vez de purgarse, se meten en la garganta dos palmos o más de una flecha, y vomitan una sustancia de color verde mezclada con sangre, y cuando les duele la cabeza se hacen un corte transversal en la frente. Además, se atan bien apretado el miembro al cuerpo a causa del mucho frío que hace y cuando uno de ellos muere, aparecen diez o doce demonios llenos de tatuajes bailando muy alegres, siendo Setebós el mayor de todos y el que más grita y alborota, y uno de los patagones apresados dijo haberlos visto, con dos cuernos en la cabeza y pelos largos hasta cubrirles los pies y echando fuego por la boca y por el culo ${ }^{21}$. Esta es la frase anterior a que Pigafetta escriba que Magallanes llamó a estos pueblos Patagones. Quizás es que el capitán mayor los vio bastante patacões, raros,

\section{9.}

20 Doura, 2011, op. cit., p. 53.

21 Pigafetta, 1999, op. cit., pp. 90-96. 
descerebrados. ¿Será que Patagonia quiere decir Tierra de Locos?

Historia aparte es la teoría del Primaleón. ¿Había leído el Primaleón Fernando Magallanes? Puede, no hay que descartarlo, aunque cabe dudarlo. Editada en Salamanca en 1512, la obra, también llamada Libro segundo del emperador Palmerín, es la continuación de una novela de caballería de gran éxito, Libro del famoso y muy esforzado caballero Palmerín de Olivia, en la que, como es sabido, aparece un personaje llamado Patagón, que es el más salvaje de los que viven en una isla a la que llega el caballero Primalión, y en la que todos van vestidos con pieles de los animales que cazan y se comen crudos.

Es del todo imposible saber si a Magallanes le gustaba leer literatura, y recurrir a su origen noble para justificarlo es incuestionablemente osado, entre otros motivos, porque de la juventud y de la vida privada del navegante portugués se sabe irritantemente poco. Por el polígrafo y conocido aventurero Fernando Oliveira, que, hacia 1570 elaboró una copia comentada del relato manuscrito conservado en la biblioteca de Leiden de alguien que participó en el viaje a las Molucas, se sabe que uno de los primeros oficios que tuvo Magallanes fue el de criado del-rei em foro de moço de câmara ${ }^{22}$. Es decir, por un lado, era alguien que recibía educación en la Casa del Rey y a quien, por ello, debía obediencia, y por el otro, era alguien que servía al rey entre la nobleza considerada de segundo nivel, bajo las órdenes del mayordomo mayor y seguramente entre los oficiales de la Mesa del Rey, según la estructura jerárquica de la Casa Real portuguesa, de la que cabe decir que es de una extrema complejidad. En cualquier caso, era

22 Valiére, 1976. Le voyage de Magellan raconté par un homme qui fut en sa compagnie. Fundação Calouste Gulbenkian, Paris, pp. 27-28; sobre Fernando Oliveira, véase Domingues, 2004. Os Navios do Mar Oceano: Teoria e empiria na arquitectura naval portuguesa dos séculos XVI e XVII. Centro de História da Universidade de Lisboa, Lisboa, pp. 36-106.

23 El dato aparece en la Ementa da Casa da Índia, Rêgo et al., 1962-1989. Documentos sobre os Portugueses em Moçambique e na África Central. Centro de Estudos Históricos Ultramarinos, Instituto de Investigação Científica Tropical, Lisboa, Vol. I, p. 110.

24 Avelar, 2002. Representações de Fernão de Magalhães na cronística da Expansão. En Academia da Marinha, Fernão hidalgo del rey y por ello recibía una pequeña pensión o moradía, por morar y servir en su Casa. Con ese rango, el 25 de marzo de 1505 embarcó con su hermano Diogo de Sousa -sus hermanos Duarte y Diogo usaban el apellido materno- en la armada del que iba a ser el primer virrey del Estado da Índia, D. Francisco de Almeida ${ }^{23}$. Esto es todo lo que se puede elucidar sobre su formación y educación.

A su vez, los grandes cronistas oficiales del viaje oceánico portugués, todos ellos escribiendo sus crónicas largos años después del viaje a las Molucas, dedicaron una atención relativa a Fernando Magallanes. Pero junto a ese desdén, también se dedicaron a elaborar una versión y una opinión oficial sobre lo que podría llamarse el caso Magallanes ${ }^{24}$. Y esa imagen sobre Magallanes pasa, por un lado, por describir la atención que el portugués prestaba a todo lo que arribaba a los muelles del Tajo -y ahí dice João de Barros que el navegante sempre andava com pilotos, cartas de marear e alturas de leste-oeste- ${ }^{25}$, y por el otro, por saber transmitir el despecho que sentía Magallanes al considerarse maltratado por el rey Manuel. Los ingredientes con los que se crea esta imagen forman muy buena combinación, porque junto al resentimiento y el disgusto, crecía también el estímulo que causaban las cartas que Magallanes recibía de su amigo Francisco Serrão desde Ternate, en las que lo animaba a emprender un viaje del que había de obtener grandes beneficios económicos. Cuenta João de Barros que Magallanes, para que D. Manuel reconociera sus méritos, añadía tantas palauras e mistérios a las informaciones que recibía de Serrão que parecia virem aquelas cartas [...] doutro novo mundo, em que tinha feito mais serviço a el-rey do que fizera o almirante $D$. Vasco

de Magalhães e a Sua Viagem no Pacífico: Antecedentes e Consequentes. Actas do VII Simpósio de História Marítima, 24 a 26 de Outubro de 2001. Academia da Marinha, Lisboa, pp. 305-321; Garcia, 2002. Fernão de Magalhães visto pelos cronistas portugueses do século XVI. En Academia da Marinha. Fernão de Magalhães e a Sua Viagem no Pacífico: Antecedentes e Consequentes. Actas do VII Simpósio de História Marítima, 24 a 26 de Outubro de 2001. Academia da Marinha, Lisboa, pp. 323328.

25 Barros, 1988-1992. Ásia de João de Barros: Dos feitos que os Portugueses fizeram no descobrimento \& conquista dos mares \& terras do Oriente. Imprensa Nacional-Casa da Moeda, Lisboa, Vol. III, Lib. V, Cap. VIII. 
da Gama no descobrimento da Índia. Aparte de la exagerada actitud de Magallanes, se desprende de las palabras de João de Barros que al portugués le interesaba leer cartas, recabar la información que le llegaba de la lejanísima Ternate y estar al tanto de tratados náuticos y mapas. Esta es aparentemente la literatura que le interesa a Magallanes, según recogen las fuentes. A su vez, también por João de Barros se sabe que Magallanes escribía a su amigo Serrão desde Lisboa o Sevilla, por unas cartas suyas encontradas por su perseguidor en aguas de las especias, el capitán António de Brito, entre los documentos de Francisco Serrão en la isla de Ternate, en las que decía que cedo se veria com ele [con Serrão]; e que quando não fosse por via de Portugal, seria por via de Castela, porque em tal estado andavam suas cousas, y añade que lo esperase, porque já se conheciam a pousada para ele esperar ${ }^{26}$. Según João de Barros, Magallanes tenía claro cómo llegar a Ternate, donde Francisco Serrão había instalado su feudo.

Y, por otro lado, también el rey Carlos recibió cartas de Magallanes, como la que le escribió el 24 de octubre de 1518, seca y directa, casi desafiante, como solía ser su tono, para contarle el violento altercado en el puerto de las Muelas, cuando colgó sus blasones de unos cabestrantes que se habían plantado en tierra junto a una nao que se iba a varar y en la que debía enarbolarse el estandarte del rey. Se avanzó Magallanes y tendió sus insignias antes que las de Carlos, por lo que se vieron claramente en Sevilla las cinco quinas de la Casa Real portuguesa $^{27}$. Creció tanto la tensión que hasta se desenvainaron las espadas, y Magallanes se ofendió mucho y así se lo hizo saber al rey; y de paso, aprovechó para reclamarle el dinero acordado para acabar de proveer la flota, ya que los funcionarios de la Casa de la Contratación lo entretenían con dilaciones $^{28}$. El rey se puso de parte de Magallanes

26 Idem.

27 Herrera, 1601-1615. Historia general de los hechos de los castellanos en las Islas y Tierra Firme del mar Océano que llaman Indias Occidentales [Décadas]. Juan Flamenco y Juan de la Cuesta, Madrid, Vol. II, cap. 4, p. 9; Garcia, 2007, op. cit., pp. 20-21; Castro, Hamon y Thomaz (Eds.), 2007, op. cit., pp. 307-308.

28 Recoge la carta Fernández de Navarrete, 1825-1837. Colección de los viajes y descubrimientos que hicieron por mar los españoles desde fines del siglo XV. Imprenta Real, Madrid, Vol. IV, pp. 124-127.

29 Se sigue en estas páginas a Loureiro, 2019. Em demanda da biblioteca de Fernão de Magalhães. Biblioteca Nacional y reprendió a todos aquellos que habían alimentado la tensión. Carlos recibió más cartas, que se iban endureciendo a medida que Fernando Magallanes se iba impacientando y enfadando por las muchas demoras y contratiempos que sufría su viaje. Magallanes era de enfadarse: con su rey, con el rey de España, con la Casa de la Contratación, con sus propios hombres en la bahía de San Julián.

Sin duda, a Magallanes le interesaba el género epistolar, y también sin duda cruzó la frontera hacia Sevilla con documentos y mapas, pero es imposible reconstruir su biblioteca, aunque se puede conjeturar sobre ella ${ }^{29}$. Por el cronista español Francisco López de Gómara se sabe que Magallanes se presentó ante Carlos I en Valladolid en 1518, entre otros documentos, con la relación de Luis Berthoman, boloñés, que fue a Bandam, Borney, Bachian, Tidore y otras islas de especias $^{30}$. Es muy probable que en la indostánica ciudad de Cochin se hubieran conocido Magallanes y el italiano Ludovico de Varthema, quien, ya de regreso a Europa, publicó en 1510 su Itinerario de Ludovico de Varthema, obra que fue rápidamente reeditada y traducida, y Magallanes, ya de vuelta a Portugal, se hizo con un ejemplar. Y otra gran obra que quizás llegó a poseer Magallanes, aunque no en su versión original, fue el Livro das Coisas do Oriente del funcionario de la feitoria de Cananor Duarte Barbosa, un documento valiosísimo que también circuló manuscrito y también llegó a manos del informado editor Ramusio ${ }^{31}$. En la primera página de una versión manuscrita y en castellano del Livro de Barbosa que se conserva en la Biblioteca Nacional de Madrid, se puede leer: este libro conpuso fernando magallanes portugués piloto lo qual el vio y anduvo, lo cual lleva a pensar que este ejemplar hubiera podido pertenecer a Magallanes ${ }^{32}$.

de Portugal, Lisboa.

30 López de Gómara, 1965. Historia General de las Indias. Guibelelde, P. y Aguilera, E. M. (Eds.), Vol. I, p. 160.

31 Ramusio, 1978-1988. Navigazioni e Viaggi. Ed. Marica Milanesi, Enaudi, Turin, Vol. II, pp. 711-780.

32 Barbosa, 1996-2000. O Livro de Duarte Barbosa. Ed. Veiga e Sousa, Instituto de Investigação Científica Tropical, Lisboa, 2 vols.; Blázquez, 1920. Descripción de los reinos, costas, puertos e islas que hay desde el Cabo de Buena Esperanza hasta los Leyquios, por Fernando de Magallanes, piloto portugués que lo vio y anduvo todo. Real Sociedad Geográfica, Madrid; Loureiro, 2019, op. cit., pp. 17-47. 
Y esto es todo lo que inequívocamente se puede decir de la biblioteca de Magallanes, aunque, obviamente, cabe pensar que a lo largo de su vida tuvo en sus manos obras fundamentales de geografía y astronomía, derroteros y literatura náutica, además de acceso a obras clásicas, como la Historia Natural de Plinio o la Geografía de Ptolomeo, el Libro de las Maravillas de Marco Polo. Quizás hasta llegó a poseer una obra inestimable, la Suma Oriental del boticario y factor de Malaca Tomé Pires, el primer gran tratado geográfico-mercantil asiático, que circuló manuscrito y que también llegó a manos del humanista veneciano Ramusio. Al menos debió de consultar el Tratado da agulha de marear de João de Lisboa, quien años antes había alcanzado el río de la Plata, o el Esmeraldo de Situ Orbis de Duarte Pacheco Pereira, o las cartas de Américo Vespucio, o la colección de relatos Paesi novamente retrovati recogidos por Francazano de Montalboddo. Y la lista de posibles obras podría ser más larga, pero entre los intereses lectores de Magallanes encaja mal una novela de aventuras caballerescas, por muy famosa que fuera (que lo fue) como el Primaleón. Aunque evidentemente no es descartable, porque en un barco se cargan muchas cosas y además hay muchas horas muertas que se pueden dedicar a la lectura. Quizás estaba el Primaleón en la nao Trinidad, quizás no era Magallanes sino Pigafetta quien lo había leído o lo estaba leyendo. Quizás fue Pigafetta quien le prestó la palabra patagón a Magallanes para que bautizara a los habitantes de aquel recóndito y salvaje lugar.

El leído era Antonio Pigafetta; de ello no hay duda porque lo dice él mismo al inicio de su relato, cuando justifica su aventura y su espíritu aventurero. Se sumó a la empresa de las Molucas, primero, por curiosidad, después, por los muchos libros que yo había leído y, en tercer lugar, por haber asistido a las conversaciones de diferentes personas con su Señoría [Philippe Villiers de l'Isle-Adam] sobre las grandes y extraordinarias cosas que había en el mar Océano. El caballero vicentino quiso ver esas cosas con sus propios ojos y al mismo tiempo, hacerme con un nombre que llegase a la posteridad ${ }^{33}$. Se reúnen en estas frases de Pigafetta una serie de inquietudes que hacen de él una mezcla de caballero andante

33 Pigafetta, 1999, op. cit., pp. 71-72.

34 Plinio. Historia Natural, Lib. VI, cap. XXXII. legendario -él mismo es caballero Hospitalario- y aventurero moderno que se siente fascinado por lo desconocido. Pigafetta es el nuevo viajero renacentista que redefine el antiguo y medieval significado de la errancia -el acto de librarse a la ventura y la conquista de la fama para la posteridadpara descubrir, entender y explicar, no un mundo que ha de ser verdadero, sino la realidad del mundo. Si termina su dedicatoria a Villiers en el más puro estilo de la novela de caballerías -en este libro están todas mis vigilias, fatigas y peregrinaciones-, el sentido y la forma de narrar los contenidos de su Notizie del Mondo nuovo convierten este documento en un ejemplo excepcional de la nueva literatura de viajes renacentista. Pigafetta da protagonismo a la observación y el detalle, y con esa herramienta científica recoge lenguas y costumbres etnográficas, describe paisajes y especies botánicas y zoológicas. Convive con las sociedades encontradas y registra sus modos de vida, sus cosmogonías, su barbarie o la sofisticación de sus organizaciones político-administrativas, sus rituales religiosos, su sexualidad, sus sistemas curativos. Pigafetta usa de tal modo su herramienta científica que muchas veces parece un prematuro viajero ilustrado. $\mathrm{Y}$ a su vez, parece un viajero humanista, al agregar al relato las pinceladas de su saber libresco, porque, por añadir dos ejemplos bonitos, ya Plinio había situado en Ombrión o Pluvialia (posiblemente La Palma o El Hierro) ${ }^{34}$ ese generoso árbol del que habla Pigafetta cuya misión en una isla sin manantiales es absorber la humedad de la niebla y destilarla en agua para ofrecerla a quien la pueda necesitar; y es Marco Polo, aunque también Sindbad en Las mil y una noches, quien describe al mítico y gigantesco pájaro Roc en el capítulo CXCII de su Libro de las Maravillas y lo sitúa en Zanzíbar, mientras a Pigafetta le han dicho que está al norte de Java ${ }^{35}$, y Theodor de Bry, mediante la imagen de Straert y Collaert, lo alegoriza más allá del estrecho magallánico para anunciar lo que les espera al otro lado del pacífico océano a las naves de las Molucas.

Sin embargo, seguramente porque escribe por encargo, a solicitud del gran maestre de Rodas, cabe sospechar que el caballero Pigafetta elige lo que quiere contar; y se alarga, tanto en

35 Pigafetta, 1999, op. cit., p. 242. 
aquello que cree que puede interesar y sorprender, como omite o silencia hechos y circunstancias que fueron cruciales durante el viaje, y son cruciales para entender qué fue aquel viaje. Se intuye tal técnica narrativa en ese propósito de registrar vigilias, fatigas y peregrinaciones con el que termina su introducción, y a medida que se avanza en la lectura se van confirmando las selectivas elecciones de contenidos que se propone ofrecer Pigafetta. En este sentido, se ha aludido a la admiración del italiano hacia su capitán mayor para señalar la distancia respecto a los violentos ajusticiamientos impuestos por Magallanes a los amotinados de San Julián; también se ha querido ver la omisión de cualquier referencia a Juan Sebastián Elcano a lo largo de todo el relato como muestra de enemistad o animadversión hacia el piloto vasco. Puede ser; aunque también puede ser que Pigafetta decidiera decir o no decir según los intereses del lector al que dirige su obra. También puede ser que Pigafetta quisiera lavar la imagen de Fernando Magallanes, muy vilipendiada tanto en España como en Portugal; o quizás creyera, como así era, que ya había muchos que estaban contando tanto la heroicidad de Elcano, como la crueldad de Magallanes. Fue parco al explicar el conflicto que, ya desde antes de la partida, existía entre el capitán y sus mandos -es decir, entre el portugués y los españoles-, malestar que Pigafetta advirtió durante los tres meses que aguardó en Sevilla mientras, con grandes estorbos desde la Casa de la Contratación, se pertrechaban las naves. Y eso se desprende del breve párrafo que da inicio al relato propiamente: Magallanes zarpaba sin decir a ninguno de sus hombres la naturaleza del viaje que quería hacer para que no le distrajeran en la preparación de algo tan grande y maravilloso, y por eso los capitanes le tenían gran odio, no por otro motivo sino porque él era portugués y ellos españoles ${ }^{36}$.

El italiano no se quiso meter en ese berenjenal que implicaba traiciones a reyes y exilios voluntarios, secretos de Estado y enfrentamientos político-geográficos. Quizás por eso debió de pensar que era mucho mejor contar las heroicidades y las crueldades del propio viaje. Y si las crueldades humanas se concentraron sobre

36 Ibidem, p. 75.

37 Laguarda, 1973. El predescubrimiento del Río de la Plata todo en la bahía de San Julián, y ahí el capitán mayor Fernando Magallanes fue implacable, las crueldades del viaje -salvo la muerte de Magallanes en la isla filipina de Mactán por descuido o exceso de confianza o por engreimiento y arrogancia o por jactancia ante el rajá Humabón de Cebú- se concentraron en Patagonia y en ese nuevo océano que a Fernando Magallanes le pareció tan pacífico. Allí se concentran también los cuatro grandes descubrimientos de la expedición a las islas de las especias.

A partir del río de la Plata el frío tomó entonces el protagonismo. El frío fue el primero de los cuatro grandes descubrimientos que hizo la armada de las Molucas. Aquel frío era algo todavía no experimentado en su máxima crueldad, al menos no en latitud Sur, por mucho que los portugueses hubieran pasado ya varias veces el tormentoso cabo de Buena Esperanza (situado a 34²0'S), como era el caso del propio Magallanes. Ahora aquellos barcos estaban mucho más al sur, en los 49³5'S, más allá del límite alcanzado por las silenciosas expediciones portuguesas anteriores ${ }^{37}$. El frío era insoportablemente doloroso, pero el capitán portugués no estaba dispuesto a tolerar flaquezas, y aún menos después de los motines y brutales ajusticiamientos ocurridos en la remota y patagona bahía de San Julián, entre cabo Curioso y punta Desengaño, muy cerca ya del cabo de las Once mil Vírgenes que abre el Estrecho. Fue larga la invernada -con días de apenas siete horas de luz, nunca por encima de los 0 grados, con medias que fácilmente descendían a -6-, y el frío acrecentaba el terror que había impuesto el aplastante sentido de la justicia de Magallanes. Pero no iba a ser el frío lo que lo detuviera, y así se lo hizo saber a sus hombres: él había de navegar hasta tanto que hallase fin a aquella tierra. Y hasta se permitió humillarlos, tal y como estaban los ánimos, al comparar su cobardía con las proezas de las que eran capaces los portugueses en sus rumbos hacia Oriente -que catasen cómo los portugueses, no cada año, mas cada día, yendo y viniendo a las partes orientales [...], pasaban casi 20 grados adelante del trópico de Capricornio hacia aquella parte del polo antártico-, así que más valía que no se quejasen, que más frío pasaban los

por la expedición portuguesa de 1511-1512. Junta de Investigações do Ultramar, Lisboa. 
lusos, y que pensasen que después del invierno llegaría el verano ${ }^{38}$.

El 21 de octubre las naves habían alcanzado los $51^{\circ} \mathrm{S}$ y Magallanes mandó la San Antonio y la Concepción a explorar lo que les había parecido una especie de bahía, según describe Fernando Albo en su derrotero ${ }^{39}$. Sin ser conscientes de ello, habían encontrado la boca del Estrecho. Tuvieron que esperar la marea propicia para entrar, y pasado el mediodía avanzaron a una velocidad de dos a tres nudos ${ }^{40}$. Entre tierras bajas se elevaba una pequeña colina, monte Dinero, a la que Magallanes mandó subir al fiel piloto João Lopes de Carvalho, pero desde alli apenas pudo interpretar la continuidad del litoral, al quedar sobrepuestas la punta Anegada de Tierra de Fuego y la punta Delgada de Patagonia, desdibujando la Primera Angostura. Ante la incógnita, el capitán mandó la San Antonio y la Concepción a explorar, una por la banda norte y otra por la sur, mientras la Trinidad y la Victoria buscaban fondeadero al norte, en el actual cabo Posesión. El viento era durísimo, habían entrado de lleno en el reino de los cincuenta rugientes, uno de los más temibles corredores eólicos del planeta, que a mediados de octubre impulsa rachas insufriblemente heladas que pueden llegar a alcanzar 70 nudos, unos 130 kilómetros por hora. Después del frío, el terrible viento fue el segundo gran descubrimiento de este viaje, y fue implacable durante cuarenta y ocho horas, dice Pigafetta ${ }^{41}$.

A tientas, iniciaron la exploración de la Primera Angostura, aprovechando la fuerte corriente, avanzando atentos a posibles bajos rocosos, hasta llegar al gran espacio interior dibujado por las bahías de Felipe, al sur, y Santiago y San Gregorio, al norte, y cerrado por la Segunda Angostura. Las naves volvieron con la noticia de que había camino y parece que fue el astrónomo Andrés de San Martín quien defendió que se debía continuar. Y eso hicieron. En la costa sur vieron fuegos y humos, y en la norte, una construcción que se les antojó llena de sepulturas (doscientas, dice Antonio Herrera), también los restos de una ballena. No vieron ni un solo habitante en aquel espacio yermo y vacío.

38 Como dice la Relación escrita por Maximiliano Transilvano recogida por Fernández de Navarrete, 18251837, op. cit., Vol. IV, pp. 249-284.

39 Fernández de Navarrete, 1825-1837, op. cit., Vol. IV, pp. 209-246.
Con rumbo sudoeste, superaron la Segunda Angostura pasando entre la punta de Gracia, en el lado patagón, y la de San Vicente, en Tierra de Fuego, para entrar en un tercer gran espacio con tres islas espectacularmente pobladas de aves, de los Pájaros las llamaron. Frente a las naves, la poderosa isla hoy llamada Dawson parecía partir el camino, por lo que Magallanes decidió separar las naves para explorar alternativas. La Trinidad y la Victoria acertaron la ruta y siguieron hacia el noroeste por el actual cabo Froward (así lo bautizó Thomas Cavendish en 1587, por hostil e incontrolable) que, al dejar atrás el Puerto del Hambre o Tercera Angostura, abre el canal Tortuoso. Entraban en el laberinto en el que se desmenuza en el mar la cordillera andina, y al final de ese angosto paso, en el cabo Crosstide, se encuentran las mareas de ambos océanos. Esperaron a las otras naves en la bahía de las Sardinas (posiblemente, la actual bahía FortescuePuerto Gallant), donde pescaron y salaron, se aprovisionaron de madera y también de mucho apio silvestre, según el piloto Ginés de Mafra. Pero la San Antonio no regresó: esta vez sí, instigada por el piloto portugués Estevão Gomes, la tripulación se amotinó contra el capitán Álvaro de Mesquita, y tomó el rumbo de regreso a España.

Fueron seis días de navegación entre murallas, desde el 23 al 28 de noviembre de 1520 , con los atentos esquifes ante las tres naves y los vigías encaramados a los palos, recibiendo de través las corrientes de los canales y el violento williwaw, el viento a ráfagas que recorre los fiordos y levanta mar de leva y veloces nubes de agua helada. Aquel paso fue un inédito desafío para los pilotos y para aquellas naves de vela cuadrada, pero el 28 de noviembre consiguieron superar el cabo Deseado. En treinta y nueve días habían recorrido los 565 $\mathrm{km}$ del Estrecho; junto al frío y el viento, este era el tercer gran descubrimiento de la armada de las Molucas, el Estrecho Patagónico. Ahora iniciaban el cuarto y último: los tres meses y veinte días de navegación por la inmensidad pacífica. El viaje estaba siendo de una dureza casi inigualable, pero

40 Se sigue en estas páginas a Martinic, 2016. Una travesía memorable: hallazgo y navegación del estrecho de Magallanes (21 octubre-28 noviembre 1520). Talleres de La Prensa Austral, Punta Arenas.

41 Pigafetta, 1999, op. cit., p. 101. 
al abandonar el laberinto austral Antonio Pigafetta escribió en su diario creo que en todo el mundo no existe un estrecho más bello que éste ${ }^{42}$.

Se abría el Pacífico ante las tres naves ese 28 de noviembre de 1520. Sorprendentemente, ese gran océano siempre enfadado se mantuvo manso mientras las naves viraban al norte con los vientos alisios del sureste y se dejaban llevar por la corriente Humboldt, hasta avistar, el primero de diciembre y hacia los $47^{\circ} \mathrm{S}$, una tierra rocosa y abrupta a la que Magallanes dio el nombre de Diciembre y que debía de ser la península de Taitao, en la actual región de Aysén ${ }^{43}$. Este fue el último contacto con el continente americano, porque a partir de entonces, las naves viraron hacia el oeste, orzadas con los alisios del hemisferio sur hasta cruzar el 13 de febrero de 1521 la línea equinoccial y seguir hacia el noroeste con los alisios del hemisferio boreal y la corriente ecuatorial del norte. Fueron tres meses y medio de navegación a ciegas, totalmente intuitiva, pero acertada. Ese acierto no evita, no obstante, que la travesía fuera descarnadamente cruel para los ciento sesenta y seis hombres que mantenían la armada de las Molucas. Pigafetta supo construir una imagen nítida del nivel de sacrificio al describir el agua pútrida, el puré de bizcocho infestado de gusanos que apestaba a orines de rata, unas ratas que se vendían a medio ducado cada una y había poquísimas, y cuando esto faltó comíamos las pieles de buey que están sobre el palo mayor para impedir que se dañen las jarcias [...] Muchas veces tuvimos que comer el serrín de las maderas. Añade el italiano que murieron diecinueve hombres de una especie de enfermedad que hacía hincharse las encías hasta el extremo de sobrepasar los dientes en ambas mandibulas ${ }^{44}$. Era peor. Los síntomas del escorbuto, desconocido para los navegantes españoles, pero no para los portugueses, quebraban el aplomo del más valiente: inflamación y endurecimiento de la piel, sobre todo en las piernas, el rostro, la garganta y las encías, que se tornaba de un color violáceo; músculos rígidos; úlceras en la boca que provocaban la caída de los dientes, impedían la ingestión de alimentos y producían un aliento repugnante; pústulas por

\footnotetext{
42 Ibidem, p. 106.

43 Martinic, 2016, op. cit., p. 182, nota 120.

44 Pigafetta, 1999, op. cit., pp. 111-112.
}

todo el cuerpo y marcas como de picaduras por las que empezaba a manar la sangre como si fuera sudor; desarrollo desmesurado del hígado y el bazo, lo cual provocaba ataques de nervios y de ira. Los hombres morían no tanto por el dolor como por asfixia (los pulmones se iban secando), deshidratación o hemorragia (porque las pústulas no cicatrizaban), o por inanición (por la falta de dientes, la hinchazón de las encías o de la garganta que impedía la ingestión de alimentos). Si Patagonia había sido el frío, el Pacífico sería el hambre.

Nunca ningún cartógrafo, ningún grabadororfebre, podrá representar lo que fue la crueldad de aquellos tres meses oceánicos. Sin embargo, esa crueldad, que contiene frío, viento, hambre y miedo, dominó el viaje a las Molucas con excepcional protagonismo. Así fue el Pacífico, el cuarto gran descubrimiento de Magallanes, hasta que el 6 de marzo de 1521 se avistaron las Marianas. Apenas mes y medio después, el 27 de abril, en el combate contra los nativos de Mactán, una flecha envenenada, dice Pigafetta, atravesó la pierna derecha del capitán; siguieron combatiendo con el agua a la altura de las rodillas; Magallanes recibió una lanzada de caña en la cara que pudo esquivar clavando su espada en el pecho del atacante, pero mientras intentaba arrancarla, otra lanza le alcanzó el brazo. Quedó rodeado y uno le atravesó la pierna izquierda con un terciado más grande que una cimitarra. El capitán cayó con el rostro hacia tierra y rápidamente se lanzaron contra él con lanzas de hierro y de caña y con aquellos terciados tan grandes, hasta matar al espejo, la luz, el consuelo y nuestra verdadera guía ${ }^{45}$. Admira a su capitán el caballero Pigafetta. Por eso, en su carta informativa a Philippe de Villiers de l'Isle-Adam pide que la fama de un capitán tan generoso no se extinga nunca, describe su incomparable fortaleza ante las mayores adversidades, defiende que era el hombre más experto de todo el mundo con los mapas y en la navegación y concluye tajante: Que esto es cierto se puede ver claramente porque ningún otro hombre tuvo tanto ingenio ni tanto valor para lograr dar la vuelta al mundo, como él casi hizo ${ }^{46}$.

45 Ibidem, p. 159.
46 Ibidem, p. 160. 
Es verdad. Magallanes casi había conseguido dar la vuelta al mundo, aunque no en un solo viaje. Le quedaba muy poco, 300 millas náuticas, desde la isla de Cebú para llegar a la moluqueña Ternate, en aguas supuestamente navegadas nueve años atrás y donde creía que le estaba esperando Francisco Serrão. No se hubieran encontrado, su amigo ya había muerto también, en marzo de aquel 1521. Muchos habían muerto; de hecho, de la armada de las Molucas quedaban ciento trece hombres que, tras quemar la Concepción, se repartieron entre las dos naves supervivientes para iniciar el camino de regreso. También el rey Manuel I de Portugal iba a morir ese mismo año, en diciembre, sin llegar a saber nunca de la odisea a las islas de las especias y sin llegar a saber nunca de la circunnavegación de la tierra.

Junto a la resistencia heroica de la nao Victoria, el nombre de Magallanes va indefectiblemente ligado a la vuelta al mundo. Sin embargo, sus descubrimientos fueron otros, fueron el frío y el viento, fueron el hallazgo del desolado Estrecho en el meridión americano y la travesía por el mayor de los océanos del planeta. Su hazaña pasó primero por una gran traición y, ya en el mar, por una gran crueldad; pasó por el sufrimiento al límite, por el hambre insoportable y la muerte implacable y paulatina, pero también por la fuerza de la voluntad. Tengo la certeza de que un viaje igual no se volverá a hacer nunca ${ }^{47}$, dice Pigafetta tras la terrible singladura del Pacífico, pero el estrecho patagón, frío, ventoso, desolado, humeante y habitado por gigantes, fue para el caballero vicentino el lugar más bello de la Tierra. No tuvo Magallanes un poeta para su epopeya, como sí lo tuvo Vasco de Gama. Pero setenta años después, Theodor de Bry hizo que el solar Apolo y la oceánica Tetis guiaran la Trinidad entre el viento y el frío de una lejana Hiperbórea en el meridión americano.

\section{AGRADECIMIENTOS}

Agradezco los comentarios del historiador de la lengua y romanista Ignacio Vázquez y su ayuda incondicional en éste y en tantos otros trabajos.

\section{BIBLIOGRAFÍA}

Alguns (1892). Documentos do Arquivo Nacional da Torre do Tombo acerca das Navegações e Conquistas Portuguesas. Lisboa: Imprensa Nacional.

Amaral, J. F. do (1995). Pedro Reinel me fez. À Volta de um Mapa dos Descobrimentos. Lisboa: Quetzal Editores.

Avelar, A. P. M. (2002). Representações de Fernão de Magalhães na cronística da Expansão. En Academia da Marinha, Fernão de Magalhães e a Sua Viagem no Pacífico: Antecedentes e Consequentes, Actas do VII Simpósio de História Marítima, 24 a 26 de Outubro de 2001. Lisboa: Academia da Marinha.

Barbosa, D. (1996-2000). O Livro de Duarte Barbosa. Veiga e Sousa, M.A. da (Ed.). Lisboa: Instituto de Investigação Científica Tropical.

Barros, J. de (1988-1992). Ásia de João de Barros: Dos feitos que os Portugueses fizeram no descobrimento \& conquista dos mares \& terras do Oriente. Lisboa: Imprensa Nacional-Casa da Moeda.

Bry, T. de (1594). Benzoni, Girolamo, Americae pars quarta: sive insignis et admiranda historia de reperta primum Occidentali India a Christophoro Columbo anno MCCCCXCII / scripta a Hieronymo Benzono Mediolanense, qui istic annis XIIII. versatus, diligenter omnia observavit; Addita ad singula ferè capita, non contemnenda scholia, in quibus agitur de earum etiam gentium idololatria; Accessit praeterea illarum regionum tabula chorographica; omnia elegantibus figuris in aes incisis expressa a Theodoro de Bry Leodiense cive Francofurtensi, anno M D XCIIII. [Francofurti]:

Blázquez, A. (Ed.) (1920). Descripción de los reinos, costas, puertos e islas que hay desde el Cabo de Buena Esperanza hasta los Leyquios, por Fernando de Magallanes, piloto portugués que lo vio y anduvo todo. Madrid: Real Sociedad Geográfica.

Camões, L. Vaz de (1989). Os Lusíadas. Edición de Álvaro Julio da Costa Pimpão. Lisboa: Ministério da Educação, Instituto de Cultura Portuguesa.

Castanheda, F. Lopes de (1979). História do descobrimento \& conquista da Índia pelos Portugueses. Oporto: Lello \& Irmão.

Castro, X., Hamon, J., \& Thomaz, L. F. F. R. (Eds.) (2007). Le voyage de Magellan: La relation d'Antonio Pigafetta et autres témoignages. Paris: Éditions Chandeigne. 
Correia, G. (1975). Lendas da Índia. Oporto: Lello \& Irmão. Domingues, F. Contente (2004). Os Navios do Mar Oceano: Teoria e empiria na arquitectura naval portuguesa dos séculos XVI e XVII. Lisboa: Centro de História da Universidade de Lisboa.

Doura, M. A. (2011). Acerca del topónimo Patagonia, una nueva hipótesis de su génesis. Nueva Revista de Filología Hispánica, LIX(1), 37-78.

Fernández de Navarrete, M. (1825-1837). Colección de los viajes y descubrimientos que hicieron por mar los españoles desde fines del siglo XV. Madrid: Imprenta Real.

Fernández de Oviedo, G. (1557). Libro XX de la segunda parte de la General historia de las Indias. Valladolid: Francisco Fernández de Córdoba.

Frade, F. C. Veiga (2002). As primeiras viagens às ilhas de Maluco. En Academia da Marinha, Fernão de Magalhães e a Sua Viagem no Pacífico: Antecedentes e Consequentes. Actas do VII Simpósio de História Marítima, 24 a 26 de Outubro de 2001. Lisboa: Academia da Marinha.

Galvão, A. (1987). Tratado dos Descobrimentos. Vizconde de Lagoa (Ed.). Oporto: Livraria Civilização.

Garcia, J. M. (2002). Fernão de Magalhães visto pelos cronistas portugueses do século XVI. En Academia da Marinha, Fernão de Magalhães e a Sua Viagem no Pacífico: Antecedentes e Consequentes. Actas do VII Simpósio de História Marítima, 24 a 26 de Outubro de 2001. Lisboa: Academia da Marinha.

Garcia, J. M. (2007). A Viagem de Fernão de Magalhães e os portugueses. Lisboa: Presença.

Garcia, J. M. (2019). Fernão de Magalhães, Herói, Traidor ou Mito: a história do primeiro homem a abraçar o mundo. Lisboa: Presença.

Guedes, M. J. (1975). As primeiras expedições de reconhecimento da costa brasileira. História Naval Brasileira, Vol. I, Tomo I, parte 2.

Herrera, A. de (1601-1615). Historia general de los hechos de los castellanos en las Islas y Tierra Firme del mar Océano que llaman Indias Occidentales [Décadas]. Madrid: Juan Flamenco y Juan de la Cuesta.

Laguarda Trías, R. A. (1973). El predescubrimiento del Río de la Plata por la expedición portuguesa de 15111512. Lisboa: Junta de Investigações do Ultramar.

Lobato, M. (2011). As especiarias indonésias na economia mundo e a génese do primeiro conflito entre potências europeias à escala mundial. En Centro de Estudos de História do Atlântico, As Ilhas e a Europa, a Europa das Ilhas. Funchal: Centro de Estudos de História do
Atlântico.

López de Gómara, F. (1965). Historia General de las Indias. Barcelona: Editorial Iberia.

Loureiro, R. M. (2019). Em demanda da biblioteca de Fernão de Magalhães. Lisboa: Biblioteca Nacional de Portugal.

Martinic, M. (2016). Una travesía memorable: hallazgo y navegación del estrecho de Magallanes (21 octubre-28 noviembre 1520). Punta Arenas: Talleres de La Prensa Austral.

Moreira, R. (2015). Pedro e Jorge Reinel (at. 1504-60): Dois cartógrafos negros na côrte de $\mathrm{D}$. Manuel de Portugal (1495-1521). Terra Brasilis, 4, https:// journals.openedition.org/terrabrasilis/1209

Pigafetta, A. (1994). Il primo viaggio intorno al mondo con il Trattato della sfera. Edición de Mario Pozzi. Vicenza: Neri Pozza Editore.

Pigafetta, A. (1999). El primer viaje alrededor del mundo. Edición de Isabel de Riquer. Barcelona: Ediciones B.

Plinio (1998). Historia Natural. Trasladada y anotada por el doctor Francisco Hernández (libros primero a vigesimoquinto) y por Jerónimo de la Huerta (libros vigesimosexto a trigesimoséptimo) y apéndice (libro séptimo, capítulo LV), Madrid: Visor Libros.

Ramusio, G. B. (1978-1988). Navigazioni e Viaggi. Edición de Marica Milanesi. Turín: Einaudi.

Rêgo, A. da Silva (1975). As Molucas em princípios do século XVI. En Junta de Investigações Científicas do Ultramar, A Viagem de Fernão de Magalhães e a Questião das Molucas. Actas do $2^{\circ}$ Coloquio LusoEspanhol de História Ultramarina. Lisboa: Junta de Investigações Científicas do Ultramar.

Rêgo, A. da Silva (Ed.) (1962-1989). Documentos sobre os Portugueses em Moçambique e na África Central. Lisboa: Centro de Estudos Históricos Ultramarinos, Instituto de Investigação Científica Tropical.

Sánchez, A. (2009). De la 'cartografía oficial' a la 'cartografía jurídica': la querella de las Molucas reconsiderada, 1479-1529, Nuevo Mundo/Mundos Nuevos, http://nuevomundo.revues.org/56899

Sandman, A. (2007). Spanish Nautical Cartography in the Renaissance. En D. Woodward (Ed.), History of Cartography. Chicago, Londres: The University of Chicago Press.

Soler, I. (2011). Derrota de Vasco de Gama. Barcelona: Acantilado.

Soler, I. (2015). El sueño del rey: viajes y mesianismo en el Renacimiento peninsular. Barcelona: Acantilado.

Thomaz, L. F. F. R. (2000). Early Portuguese Malacca. 
Macao: Comissão Territorial de Macau para as Comemorações dos Descobrimentos Portugueses, Instituto Politécnico de Macau.
Valiére, P. (1976). Le voyage de Magellan raconté par un homme qui fut en sa compagnie. Paris: Fundação Calouste Gulbenkian. 